\title{
A Novel Hybrid Compound LLP2A-Alendronate Accelerates Open Fracture Healing in a Rabbit Model [Corrigendum]
}

Wang Z, Zhao Y, Zhang D, et al. Drug Des Devel Ther. 2019;13:1077-1086.

Following a review of the article, the authors noticed errors in the main text. The following statements below have been corrected:

Page 1078, column 1, line 12, the text:

"In order to solve this dispute, we tried to synthetize a novel chemical compound which could directly enhance autologous MSCs migrating to the fracture gap instead of any cell purification or gene modification" should read:

"Here, we evaluated a novel chemical compound which could directly enhance autologous MSCs migrating to the fracture gap instead of any cell purification or gene modification. ${ }^{24,}$

Page 1078, column 1, line 27, the text:

"Thus, we conjugated LLP2A to alendronate (Ale), a kind of bisphosphonate with high affinity for bone, which served as a bone-seeking component to direct both the cells and the compound to bone" should read:

"LLP2A conjugated to alendronate (Ale), a kind of bisphosphonate with high affinity for bone, could serve as a bone-seeking component to direct both the cells and the compound to bone. ${ }^{31-34 \text {, }}$

Page 1078, column 1, line 40, the text:

"Our previous experiments in mice have demonstrated that LLP2A-Ale was able to increase homing of the transplanted MSCs to the fracture site, which consequently accelerated closed fracture healing" should read:

"Previous experiments in mice have demonstrated that LLP2A-Ale was able to increase homing of the trans- planted MSCs to the fracture site, which consequently accelerated closed fracture healing. ${ }^{24,}$

Page 1084, column 1, line 2, the text:

"Our research group has previously reported that engraftment efficacy can be increased via the "bonetargeting" agent LLP2A-Ale, which improves the homing of transplanted MSCs to the fracture callus, using a mouse model with closed fracture. ${ }^{24}$ " should read:

"It has previously been reported by Yao et al that engraftment efficacy can be increased via the "bonetargeting" agent LLP2A-Ale, which improves the homing of transplanted MSCs to the fracture callus, using a mouse model with closed fracture. ${ }^{24,}$

\section{References}

31. Guan M, Yao W, Liu RW, et al. Directing mesenchymal stem cells to bone to increase bone formation. Nat Med. 2012;18(3):456-462.

32. Yao W, Guan M, Jia JJ, et al. Reversal of bone loss induced by estrogen deficiency or aging by guiding the mesenchymal stem cells to bone. Stem Cells. 2013;31 (9):2003-2014.

33. Yao W, Lane NE. Targeted delivery of mesenchymal stem cells to bone. Bone. 2015;70:62-65.

34. Mohan G, Lay EYA, Berka H, et al. A novel hybrid compound LLP2A-Ale both prevented and rescued the osteoporotic phenotype in a mouse model of glucocorticoidinduced osteoporosis. Calcif Tissue Int. 2017;100(1): 67-79.

The authors apologize for this error. 


\section{Publish your work in this journal}

Drug Design, Development and Therapy is an international, peerreviewed open-access journal that spans the spectrum of drug design and development through to clinical applications. Clinical outcomes, patient safety, and programs for the development and effective, safe, and sustained use of medicines are a feature of the journal, which has also been accepted for indexing on PubMed Central. The manuscript management system is completely online and includes a very quick and fair peer-review system, which is all easy to use. Visit http://www. dovepress.com/testimonials.php to read real quotes from published authors. 